\title{
Shaktipat Laser for Surgery of the Injured Souls
}

\author{
Jai Paul Dudeja \\ Professor and Director, Amity University Haryana, Gurgaon 122413, India. \\ drjpdudeja@gmail.com, Mobile: $91-9312247845$
}

\begin{abstract}
Since time immemorial the man is wishing and trying to lead a peaceful and happy life. Despite attempting different methods, the man is still not able to get an emotionally balanced and peaceful life to his complete satisfaction. This is primarily because of certain situations when his soul gets injured or wounded by other people (including colleagues and relatives), own fears and hallucinations, circumstances, incidents or accidents. Not able to cope up, the man with the wounded soul subsequently seeks medical and/or spiritual help from self/others depending on his accessibility and practiced faith. 'Shaktipat' in Hinduism is one such powerful treatment in which the enlightened master or Almighty God Himself transmits his spiritual power not only to lead the recipient to a peaceful, purposeful and emotionally balanced life but also to dramatically enhance the spiritual quotient of the seeker. The transmitter of Shaktipat (Guru/God) tunes to the parameters of the intended recipient, just like the parameters of a laser beam for the laser-target interaction process. This author, therefore, terms this metaphorical laser as 'Shaktipat Laser', which can be used not only to heal the injured souls but also for the remarkably high spiritual upliftment of the recipient, at times merging the spiritual levels of the Guru and the recipient, as one.
\end{abstract}

Keywords: Shaktipat laser, kundalini, injured soul, healing, baptism, Pentecostalism, surgery, spiritual transmission

\section{WHAT IS SHAKTIPAT?}

Derived from the Sanskrit words, shakti (energy or power) and pat (pronounced as 'paat', means to fall on), Shaktipat, in Hinduism, is a willful and one-way transmission (or conferring) of spiritual energy by one person upon another. This transmission of spiritual energy is from the higher realms of consciousness and refers to the grace and act of a Guru or spiritual Master or God Himself, conferring a form of spiritual 'Power' or 'Awakening' on the recipient [1]. Shaktipat brings about a quick and thorough spiritual transformation of the recipient. It is instant and spontaneous. Shaktipat transfers can be performed in various ways, for example through gaze, sound, thought, objects, or even remotely. It often has a profound effect on the life of the recipient, contributing to his spiritual elevation. It is said that the very consciousness of the God or Guru enters into the Soul or Self of the recipient. Shaktipat burns and cleanses the karmic baggage. It is like a change in the software of the soul, each time one receives Shaktipat.

Such a spiritual-energy-transmission plants a seed of awakening, and supports one in further self-refinement and eventual spiritual upliftment. Such transmissions are key for the light (Soruba, Divya, golden, rainbow, diamond, etc.) body activation and for the further pursuit towards self-realization, self-perfection and immortality in the physical form and later on, towards the transcendence of the consciousness [2]. Shaktipat transmissions offer direct experience of meditative absorption, deeper and subtler perception of the self, expansion of awareness (consciousness), experience of various spiritual phenomena, samadhi, equanimous blissful space-like empty being. These transmissions are to support one's individual consciousness expand beyond the physical, mental, emotional or intellectual into a vast possibility of self-being and manifestation. These transmissions support one in bringing up and facing one's conditionings, impurities and impediments in one's consciousness that act as obstruction (called energy blockages) for one's further evolution.

In Kashmir Shaivism, depending on its intensity, Shaktipat can be classified as [3]: (i) Tivra-tivra-shaktipat: the so-called "Super Supreme Grace", (ii) Tīvra-madhyashaktipat: "Supreme Medium Grace", (iii) Tīvra-mandashaktipat: "Supreme Inferior Grace", (iv) Madhya-tivrashaktipat: "Medium Supreme Grace", (v) Madhyamadhya-shaktipat: "Medium Middle Grace", (vi) Madhyamanda- shaktipat: "Medium Inferior Grace", and (vii) Manda shaktipat: "Inferior Grace".

The first ever Shaktipat happened with the first creation, when life entered matter and became a living being. That was a demonstration of Love and the Shaktipat, which is life; it was a gift of the Almighty. Life itself was the first of Shaktipats. Thenceforth, every Shaktipat that happened from every Master who represents the Guru Principle or the Almighty Himself has been transforming lives and bringing them, in awareness, to the level of the Guru or the Almighty.

\section{WHO CAN TRANSMIT SHAKTIPAT AND TO WHOM?}

Shaktipat is considered an act of grace (anugraha) on the part of the Guru or the Divine. It cannot be imposed by force, nor can a receiver make it happen. It is one-way transmission. When the Guru/God and disciple are spiritually linked, the Guru's (or God's) powers automatically flow to the disciple. Shaktipat is the transmission of appropriate-frequency waves from Guru to disciple [4]. The powerful thought waves, energy waves 
and spiritual waves of the Guru pass through that link to the disciple.

The type of aspirant who receives shaktipat most easily is the one who is innocent and childlike. Such disciples accept the Guru completely. It requires a lot of faith, love, surrender and childlike simplicity, but the result is wonderful, even beyond words.

Singh and Singh [5] conducted a study to find out the effect of Shaktipat meditation on the anxiety of students. An experiment was conducted on 152 students on the basis of non-randomized control group pre-test post-test design. Analysis revealed that Shaktipat Meditation was an effective practice to reduce the anxiety of these students. High, average and low Emotional Intelligence (EI) of different age categories (20 to $23 ; 24$ to $27 ; 28$ to 32 years) of students had benefited from shaktipat meditation when pre-anxiety and pre-non-verbal intelligence (NVI) were statistically controlled.

\section{CAN EVERY RECIPIENT OF SHAKTIPAT HAVE THE SAME SPIRITUAL UPLIFTMENT?}

The answer is 'No'. The degree of spiritual effect and the intensity of reception of shaktipat wave depend on the receptivity, detectivity, bandwidth and sensitivity of the sensor (that is, the individual soul). The effect is generally proportional to the degree of madness, craze or keenness, coupled with the surrender and innocence of the seeker to receive the grace of God or the spiritual Master. The Guru or God does not transmit shaktipat to everyone. First and the foremost criterion of the recipient is that he/she should be a 'supatra' (a really deserving soul).

\section{IS 'SHAKTIPAT' THE SAME AS 'KUNDALINI AWAKENING'?}

The spiritual transmissions of energy waves from the Guru go straight down to muladhara chakra and there they disturb the sleeping kundalini. The nature of kundalini is not sattvik; it is tamasik. If you do not awaken your kundalini, it will remain dormant, not only for one lifetime but for many lifetimes together. The nature of sushumna nadi, the channel through which kundalini ascends, is also tamasik. So when the Guru and disciple are linked, and the energy waves of the Guru pass through the disciple, they go straight to muladhara chakra where they disturb the sleeping kundalini.

Theoretically all spiritual systems aim at awakening Kundalini. However, there is a big difference in practice. There are hardly one or two instances known when an aspirant has been able to awaken his Shakti by personal efforts. The author of Shiva Sutras rightly expounds that there is only one way of awakening Kundalini, that is, by the "grace of a Guru". We may, therefore, accept theoretically that all spiritual efforts aim at awakening Kundalini, but in practice, the awakening of kundalini is more easily possible through Shaktipat [6]. This does not mean that other efforts such as worship, meditation, devotion and study of spiritual books have no bearing. These are necessary and, in fact, are required to be practised so that our Consciousness develops necessary receptivity for the Shaktipat initiation. An aspirant should always have his goal in view, while doing these practices. In this manner he develops an intense desire for achieving the higher objective. The feeling of detachment towards the world also develops in time, which helps his Shakti become active and introspective soon after Shaktipat initiation. The state of surrender to God is attained automatically after the awakening of Kundalini and the easiest way is by Shaktipat.

The doctrine of shaktipat has continued down to the present day. There have been a number of modern Indian exponents of it: two of the most notable in the twentieth century being Swami Muktananda of Ganeshpurī (190882) and his lineage; and Swami Vishnu Tirtha of Rishikesh (d. 1969) and his lineage. [6]

Shaktipat is in a way an injection of Shakti. The master injects a current of psychic power in the astral body of the initiated, by the touch of his hands, by casting a look or by speaking out to him some word or words called mantras, or any one of God's holy names, or simply by a mere thought. When the Divine Power is transmitted, it acts for the favoured (recipient) in such a way that the dormant power of kundalini is awakened. With shaktipat, the recipient needs to do absolutely nothing, only surrender. The person giving shaktipat acts an instrument for the Shakti energy to flow into the person receiving.

Shaktipat Deeksha is also known as Vedha Deeksha. The term vedha literally means piercing through, because the Guru rouses the kundalini and makes Her pierce through the six chakras of the recipient. The kundalini awakening through shaktipat triggers the spontaneous occurrence, by stages, of aspects of hatha-yoga, mantra-yoga, laya-yoga, and jnana-yoga within the practitioner. Thus it is referred to the yoga of kundalini as 'Mahayoga', the Great Yoga, and as Siddha yoga, because it is acquired "only through the favour of a perfect master (Siddha Guru)", without any effort on the part of the initiated.

When your mind gets influenced spiritually as if some spirit has taken possession of your body and under that influence different postures of yoga are involuntarily performed, without the least pain or fatigue and you feel increasingly buoyant, and simultaneously, strange sort of breathing exercises start, one starts thinking that the Divine Power of Kundalini has come into action. The Kundalini energy has also been known by western mysticism as "The Mystical Marriage."

\section{WHAT IS THE SUPREME SOUL?}

Supreme Soul is the one from which individual souls emerge and merge again in space and time. Hence, the 
Supreme Soul is referred to as God, the Almighty. Supreme Soul is also referred as: Super Soul/Super Energy/ Super Spirit and, it is all pervasive and infinite in nature. Paramatma is the Supreme Principle, whatever we call it: God, Supreme Self, Divine Self, Love, Truth, Supreme Soul, or Reality.

\section{WHAT IS AN INDIVIDUAL SOUL AND SELF?}

The Self (or Atma) may be described as God's ray of light, which exists as the "light of life" in every living being. It is a part of Paramatma (Supreme Soul) and is therefore identical in nature with it. Just as the seed of a tree contains all the qualities of the tree, the Self (Atma) also carries the qualities of the Supreme Soul.

The individual soul (or Jivatma), is the reflection of the Self (Atma) within an individual; a "wave" that emerges from the ocean of existence and wanders from embodiment to embodiment, and after a long process of development and experience, again returns to the unity of the Self (Atma). The soul that has manifested itself in a form, however, does not identify with its divine essence but rather with its attributes, the physical body, the mind, the thoughts, etc. This is the individual soul.

What is the reason that the individual soul separates from God? The cause lies in the ego. Here ego means 'the will to exist'; it is the aspiration for manifestation and selfexpression in the sense of "I want to exist". Ego is the seed from which the variety within nature comes into existence. The difference in form is relevant only to the external manifestation and to the expression of consciousness and intellect; the essence, however, is the same within all that is the 'soul'.

\section{WHAT IS AN 'INJURED SOUL'?}

\section{Definition of an injured soul:}

Soul injury is defined as an overlooked, un-assessed wound that separates one from their "real self" that causes a person to feel personally defective, inadequate, or unworthy [7]. In short, a damaged, a wounded or an injured soul is that, which is in need of spiritual healing or a 'shaktipat'.

Following are the causes of most of the soul injuries:

- Unmourned loss and unforgiven guilt/shame that is often manifested as a sense of emptiness, loss of meaning, or a sense that a part of self is missing.

- Disruption of a person's fundamental identity which shrinks his sense of inner goodness and beauty, fueling a haunting sense that he might be defective or tainted.
- Lack of vitality, vague emptiness, profound aching or sense of meaninglessness caused by disconnection from the part of self carrying the emotional pain.

Who are at risk for developing a soul injury? Some Examples:

- Victims of sexual assault, crime, accidents, natural disasters, bullying, neglect, domestic violence.

- People who have experienced heartache, loss of personal health or a loved one's health, death of a loved one, or betrayal by a significant other.

- Minorities and marginalized members of a society, culture, or group.

- Stoic cultures that hide or are ashamed of expressing emotional pain.

- Veterans and First Responders, their families, civilians who experienced a war zone.

- Personal and professional caregivers vulnerable to "burn-out," "compassion fatigue," and secondary traumatic stress.

Dr. Joseph E. Murray, (1919-2012), 'Father of Transplantation' and pioneer plastic surgeon won the Nobel Prize in 1990 in Physiology or Medicine. He was a pioneer of organ transplantation, Dr. Murray's autobiography 'Surgery of the Soul: Reflections on a Curious Career' published in 2001 provides wonderful insights into an outstanding career of the 93-year old master surgeon [8]. It also tells a wonderful story of how surgery treats the souls of the patient and the surgeon, as well as the disease. This book reveals the curiosity, tenacity, optimism, and humanity of a remarkable surgeon and scientist as well as the courage of his colleagues in their quest to understand the complexities of organ rejection despite discouraging setbacks. It also reflects the gratitude of the patients whose suffering Joseph Murray sought to relieve and to whom he has dedicated his life. It is a story about overcoming adversity and about healing

\section{IS 'SHAKTIPAT' SAME AS 'SPIRITUAL HEALING'?}

The answer to the question raised here is: 'Not exactly'. It is 'yes' in one situation, and 'no' in the other situation, as explained below. The basic principle behind any method of spiritual healing is to increase the spiritual purity (Sattva) and reduce spiritual impurity (Raja-Tama). Unlike Shaktipat, the spiritual healing can be done on ourselves or on others. While it may seem appealing to visit someone for spiritual healing it is possible for some people to perform spiritual healing on themselves. There are some simple techniques which are easy to heal oneself spiritually. In addition, doing regular spiritual practice is also a form of spiritual healing. In fact, doing appropriate 
spiritual practice (meditation, for example) is the most sustainable long term spiritual healing method since it increases one's spiritual capacity to overcome the spiritual negativity from within.

\section{IS 'SHAKTIPAT' IN HINDUISM SAME AS 'BAPTISM' IN CHRISTIANITY?}

According to Christianity, receiving shaktipat initiation is equivalent to being baptized by the Spirit. John, the Baptist, initiated disciples the same way a Shaktipat guru does. Even though he was not a fully enlightened master, a Christ, he was a powerful yogi with the ability to transmit Shakti to ripe seekers. Innumerable yogis have awakened to the Spirit without the help of a human intermediary, but the Grace flowing through a Master, or even an advanced teacher, can often trigger the Spiritbaptism of a disciple. Visiting the empowered spiritual places, such as holy temples and sacred burial grounds, can also facilitate spiritual initiation. Once you awaken to the Spirit (kundalini), you can rest in its power and mystically (or yogically) contemplate the Divine. In Christian mysticism, this stage of contemplation is termed 'infused contemplation'.

Those who are familiar with Pentecostal Christianity will know that in Pentecostalism too, one sees evidence of the transmission of the spiritual energy through a special touch, usually the laying on of hands by the community, or by a bishop or minister [9]. (Pentecostalism or Classical Pentecostalism is a renewal movement within Protestant Christianity that places special emphasis on a direct personal experience of God through baptism with the Holy Spirit. The term Pentecostal is derived from Pentecost, the Greek name for the Jewish Feast of Weeks). As a result of this "Christian Shaktipat", people get spiritual gifts or charismas such as speaking intongues (a Christian mantra?), prophesying, and healing. Great love for other people begins to fill the heart. One also becomes deeply fond of spending time in prayer. These and other gifts come spontaneously and effortlessly as the Spirit prompts. In fact a large number of people believe that Jesus Christ Himself was a Shaktipat Guru [10].

\section{WHAT ARE LASERS, THEIR PROPERTIES AND APPLICATIONS?}

Being a laser scientist and a teacher, this author can write hundreds or thousands of pages as an answer to this question. But the relevant and brief answer, required for the general reader of this paper, will be covered herebelow in a few sentences.

A laser (acronym for 'Light Amplification by Stimulated Emission of Radiation') is one of the few most significant inventions of the twentieth century which has got unique properties or characteristics. A laser is a highly bright and a highly monochromatic (single wavelength or a single frequency) source. Its brightness is far higher than that of the all-power natural source of light and radiation, that is, the sun. The laser bean can be focused to very small spots on a target. A laser beam has a very high degree of directionality, which means that, it can travel very large distances without its spot-size diverging much. For this case of the highest directionality, one says that the laser beam is radiating in the lowest transverse mode. All the laser sources can be categorized into two categories: either they emit the radiation continuously (cw or 'continuous wave' sources) or else, the radiation is emitted in pulses. The pulse repletion rates could vary from a few pulses per minute to millions of pulses per second. The duration of each of these pulses can vary from as large as a few milliseconds to as incredibly small as atto-seconds (1 attosecond $=10^{-18}$ seconds). There is no other man-made or any natural source of radiation, which has got all these characteristics.

Hundreds of lasers are available in the market emitting thousands of wavelengths and having other parameters listed above. When the first laser (which was a Ruby laser) was demonstrated to the world in 1960, a term was coined for the laser device: which was 'a solution looking for a problem'. Lasers have got a large, very large number of applications in a broad spectrum of life and destruction. For example, a laser beam can treat a defective eye; on the other hand the laser beam can blind a person. It can carry a fantastic amount of information over thousands of kilometers. It can drill holes in metals as hard as a diamond; it is routinely being used as barcode scanner by the counter girl sitting near the exit gate of a departmental store. This list can go on and on. For every specific application, the user or the operator of the laser has to set its parameters: its brightness, its wavelength (or frequency), its degree of directionality, degree of focusability, degree of coherence, pulse repletion rate, pulse duration, particular transverse mode of transmission etc. Surgery is one of the important applications of lasers. In this case, the laser beam falls only on the intended spot in the human body without affecting the neighboring tissues, and with the minimum loss of blood. It is therefore termed as the 'bloodless knife' used in surgery.

\section{WHAT IS A 'SHAKTIPAT LASER'?}

'Shaktipat Laser' is a new term, a metaphorical term, coined by the author of this paper. It is synonymous to the 'Spiritual Laser'. But who knows? Today's metaphorical laser, with the specified parameters, may become tomorrow's real laser for surgery of the injured souls. This laser exploits all the unique properties of a laser beam, mentioned above, to transmit very highly intense and bright spiritual energy in a highly directional, highly focused, in a highly coherent manner and in the synchronized mode (a particular frequency) to the affected souls. It is the Shaktipat transmission through this laser from a Guru or God Himself to a chosen soul. 


\section{WHO IS THE OPERATOR AND 'PARAMETERS-SETTER' OF SHAKTIPAT LASER?}

The operator of 'Shaktipat laser' is the the spiritual Master or God Himself who varies the parameters of this laser to create the maximum impact on the intended/specially chosen recipient/disciple/seeker. These parameters will be different for different recipients so that the transmitted beam from the shaktipat laser is completely in sync with the recipient.

\section{APPLICATION OF SHAKTIPAT LASER FOR SURGERY OF INJURED SOULS}

Thus we have seen that the metaphorical shaktipat laser is the most suitable device, which can not only perform surgery on the injured souls but it can transcend their consciousness for the merger of the transmitter-recipient souls. For example, some people have investigated that the spiritual awakening frequency (or kundalini awakening frequency) starts at $7.5 \mathrm{~Hz}$, ramps down to 3.5 $\mathrm{Hz}$ gradually in 5 minutes and again ramps up to $7.5 \mathrm{~Hz}$ to finish [11]. The body then becomes an effective antenna for the $7.5 \mathrm{~Hz}$ frequency, which is one of the resonant frequencies of the ionosphere. In layman's terms, you then pick up information from the air at this frequency. The shaktipat laser could be set to these frequencies, for the kundalini awakening.

\section{CONCLUSION}

Shaktipat is an instant transmission of spiritual energy from the Guru or God Himself to the deserving recipient. The parameters of this transmitted energy have to be varied, tuned and customized to the needs of the recipient. It is similar to the change in parameters of a laser beam depending on the material in the laser-material interaction process. Therefore this transmitter is metaphorically termed as 'Shaktipat Laser' by this author, which can be used by the Master of this laser to not only perform the surgery on the injured souls of the recipient targets but, much more than that, transform the disciple to the higher realms of consciousness. Shaktipat process has equivalence in many religions and faiths and hence this process of falling of spiritual grace from Above is independent of religion and spiritual faith.

\section{REFERENCES}

[1] http://www.inselfyoga.com/m/forums/topic/Grace-energySwami-Hariharananda-2016-08-11/1/7127/\#7127

[2] https://www.siddhantayoga.com/shaktipat.html

[3] Swami Lakshmanjoo (Author) and John Hughes (Editor), "Kashmir Shaivism: The Secret Supreme", Universal Shaiva Fellowship, 2003.

[4] Swami Satyananda Saraswati, Shaktipat, http://www.yogamag.net/archives/1983/gjuly83/shaktip.shtm 1

[5] Singh, T. and Singh, A., "Effect of Shaktipat Meditation on Anxiety in Relation to the Emotional Intelligence and Age"
Journal of Exercise Science and Physiotherapy, Vol. 6, No. 1: $28-33,2010$

[6] Swami Shivom Tirth, "A Guide to Shaktipat", Devatma Shakti Society, 1997.

[7] "Soul Injury at a Glance", https://www.macycatheter.com/wpcontent/uploads/2018/05/ Soul-Injury-Fact-Sheet.pdf

[8] Murray, Joseph E., "Surgery of the Soul: Reflections on a Curious Career", ISBN 0-88135-256-X, 2nd printing, minor revisions, 2012.

[9] Romain, Philip St., "Kundalini Energy and Christian Spirituality: A Pathway to Growth and Healing", The Crossroard Publishing Co., 1991.

[10] Swami Shraddhananda, "Jesus Was a Shaktipat Guru", Sacred Feet, 2014

[11] https://www.binauralbeatsmeditation.com/ 